УДК 657.1

DOI: https://doi.org/10.26642/jen-2019-4(90)-176-182

В.Ю. Царук, к.е.н.

Тернопільський національний економічний університет

\title{
Шляхи вирішення агентської проблеми в корпоративному управлінні: роль бухгалтерського обліку
}

\begin{abstract}
Обірунтовано дочільність проведення наукових досліджень у напрямі вирімення агентської проблеми в корпоративному управлінні. Розглянуто історичні аспекти формування теоретичних засад виникнення явища інформаційної асиметрії. Проаналізовано види інформаційної асиметрї та їх характеристики. Розглянуто вплив наслідків виникнення інформаційної асиметріі (несприятливий відбір, моральний ризик, утримання) на діяльність корпоративних структур. Проаналізовано иляхи мінімізації негативного впливу агентської проблеми на діяльність корпоративних структур. Виокремлено дві групи підходів дослідників до вирішення агентськоі проблеми в контексті існування нормативно-позитивної дихотомії щьодо методологї здійснення досліджень. Обтрунтовано необхідність врахування особливостей внутрішнього та зовнішнього середовища корпоративної структури при виборі методів мінімізації негативних наслідків виникнення агентської проблеми. Визначено иляхи удосконалення бухгалтерського обліку в напрямі мінімізації негативних наслідків виникнення агентської проблеми.
\end{abstract}

Ключові слова: корпоративне управління; агентська проблема; інформаџійна асиметрія; облікова інформачія.

Актуальність дослідження та постановка проблеми. В умовах сьогодення ефективний розвиток систем корпоративного управління значною мірою залежить від здатності керівництва корпоративної структури створити необхідні умови, які забезпечать мінімізацію агентської проблеми. Агентська проблема полягає в можливості зловживання агентами своїми повноваженнями, що може призвести до розходження інтересів агентів та принципалів і в цілому буде негативно впливати на діяльність корпоративної структури.

Однією з причин виникнення агентської проблеми в корпоративних структурах є інформаційна асиметрія між принципалами та агентами, що проявляється у вигляді існування прихованих характеристик, здійснення прихованих дій та наявності прихованих намірів, і яка уможливлює здійснення агентами опортуністичної поведінки. Наслідками такої поведінки, які негативно впливають на діяльність корпоративної структури, можуть бути несприятливий відбір кандидатів на посади агентів, виникнення морального ризику та існування прихованих намірів щодо подальшої діяльності агентів. Тому одним 3 актуальних питань, що потребують уваги вчених, $\epsilon$ пошук і аналіз можливих шляхів мінімізації агентської проблеми, зокрема на основі удосконалення облікової системи корпоративної структури, яка є основним джерелом інформації, що використовується принципалами для моніторингу і аналізу діяльності агентів.

Аналіз останніх наукових досліджень і публікацій. Питанням ідентифікації та вирішення агентської проблеми присвячені праці представників інституційної теорії - А.А. Берлє, О.Вільямсона, М.К. Дженсена, Г.Демсеца, К.М. Ейзенгардт, Р.Коуза, Г.К. Мінза, В.Х. Меклінга, Ф.Найта та ін. Питанням облікового забезпечення управління агентськими витратами присвячені дослідження К.Ю. Воронової, В.М. Жука, Г.Г. Кірейцева, В.В. Панкова, С.М. Полєнової, М.А. Проданчука, І.Б. Садовської, Л.А. Чайковської, І.А. Юхименко-Назарук та ін.

Формулювання мети статті. Основним завданням статті $\epsilon$ аналіз шляхів вирішення агентської проблеми в корпоративному управлінні та встановлення ролі бухгалтерського обліку в цьому процесі.

Викладення основного матеріалу дослідження. Проблему існування асиметрії інформації на ринках та в діяльності організацій вчені почали порушувати наприкінці 1960-х - початку 1970-х років. Значний внесок у розвиток цього напряму досліджень здійснили К.Ерроу, Дж.Акерлоф, Дж.Стігліц та М.Спенс, яким у 2001 році була вручена Нобелівська премія з економіки за внесок в «аналіз ринків 3 асиметричною інформацією». Так, Дж.Акерлоф [1, с. 91], аналізуючи ринок уживаних автомобілів («ринок лимонів»), встановив, що у випадку існування інформаційної асиметрії відбувається поступове зниження якості товарів та розмірів ринків. Хоча здійснені дослідження не стосувалися безпосередньо діяльності організацій, зокрема, корпоративних структур, автором було виявлено і розглянуто вплив інформаційної асиметрії на обсяги агентських витрат, які здійснюються з метою мінімізації даного явища. Відповідно, Дж.Акерлоф обгрунтував, що на відміну від підходу неокласиків, який передбачав існування ринку з повною і досконалою інформацією, доступною для всіх його учасників, всім ринкам і організаціям притаманна неповнота інформації, а забезпечення інформаційної симетрії шляхом одержання додаткової необхідної інформації всіма учасниками контрактних відносин передбачає необхідність здійснення витрат. 
Якщо значна увага праці Дж.Акерлофа приділялася передконтрактній поведінці агентів на ринках, то у статті 1976 року «Теорія фірми: управлінська поведінка, агентські витрати та структура власності» М.К. Дженсен та В.Х. Меклінг розглянули проблему постконтрактної поведінки менеджерів в умовах асиметрії інформації на рівні фірми в контексті існування агентської проблеми, обгрунтувавши існування морального ризику в результаті існування конфлікту інтересів між агентами та принципалами.

Авторами [12, с. 308] було встановлено, що агентські витрати слід розглядати як критерій визначення ефективності діяльності фірми, до складу яких вони зарахували такі складові: 1) витрати на моніторинг принципалами; 2) витрати на зв'язок з агентами (сигналізування та гарантування); 3) залишкові втрати. Агентські витрати за цим підходом слід розглядати як втрати вартості для акціонерів, які виникають внаслідок розходження інтересів між принципалами та агентами. Виділення наведених вище видів витрат базувалося на положеннях Дж.Акерлофа, зокрема, перші два види витрат спрямовані на усунення інформаційної невизначеності, а третій вид - відображає можливість існування неповної інформації. Пропозиції М.К. Дженсена та В.Х. Меклінга щодо вирізнення агентських витрат заперечували твердження представників неокласичної теорії про те, що витрати на процес укладання і реалізації контрактів або дорівнюють нулю, або вже враховані виробничою функцією в неявному вигляді.

Сучасні представники неоінституційної теорії, на відміну від першопроходців цього наукового напряму (наприклад, К.Ерроу [7, с. 303-305]), вже більш детально розкривають види інформаційної асиметрії, враховуючи більшу кількість факторів, що призводять до їі виникнення (табл. 1).

Таблиия 1

Види інформаційної асиметрії та їх характеристика за А. Пікотом, Р. Рейхвальдом та Р.Т. Вігандом [14, с. 50]

\begin{tabular}{|c|c|c|c|c|c|c|}
\hline $\begin{array}{l}\text { Інформачійна } \\
\text { асиметрія } \\
\text { Критерій } \\
\text { диферениіаиії }\end{array}$ & \multicolumn{3}{|c|}{$\begin{array}{c}\text { Приховані } \\
\text { характеристики }\end{array}$} & \multicolumn{2}{|c|}{$\begin{array}{c}\text { Приховані } \\
\text { дї }\end{array}$} & $\begin{array}{c}\text { Приховані } \\
\text { наміри }\end{array}$ \\
\hline $\begin{array}{l}\text { Інформаційна } \\
\text { проблема } \\
\text { принципала }\end{array}$ & \multicolumn{3}{|c|}{$\begin{array}{c}\text { Якісні характеристики } \\
\text { ефективності партнера по } \\
\text { контракту невідомі }\end{array}$} & \multicolumn{2}{|c|}{$\begin{array}{c}\text { Зусилля партнера по } \\
\text { контракту невідомі, } \\
\text { неможливо за ними } \\
\text { спостерігати, відсутні } \\
\text { підстави для суджень }\end{array}$} & $\begin{array}{c}\text { Наміри } \\
\text { партнера по } \\
\text { контракту } \\
\text { невідомі }\end{array}$ \\
\hline $\begin{array}{c}\text { Причина } \\
\text { проблем чи } \\
\text { істотних } \\
\text { факторів впливу }\end{array}$ & \multicolumn{3}{|c|}{ Приховування характеристик } & \multicolumn{2}{|c|}{$\begin{array}{c}\text { Моніторинг можливостей } \\
\text { та витрат }\end{array}$} & $\begin{array}{c}\text { Залежність від } \\
\text { ресурсів }\end{array}$ \\
\hline $\begin{array}{c}\text { Поведінкова } \\
\text { свобода агента }\end{array}$ & \multicolumn{3}{|c|}{$\begin{array}{c}\text { До початку підписання } \\
\text { контракту }\end{array}$} & \multicolumn{2}{|c|}{$\begin{array}{c}\text { Після підписання } \\
\text { контракту }\end{array}$} & $\begin{array}{c}\text { Після } \\
\text { підписання } \\
\text { контракту }\end{array}$ \\
\hline Проблема & \multicolumn{3}{|c|}{ Несприятливий відбір } & \multicolumn{2}{|c|}{ Моральний ризик } & Утримання \\
\hline \multirow{2}{*}{$\begin{array}{c}\text { Тип вирішення } \\
\text { проблеми }\end{array}$} & \multicolumn{2}{|c|}{$\begin{array}{c}\text { Усунення інформаційної } \\
\text { асиметрії за рахунок }\end{array}$} & \multirow{2}{*}{ 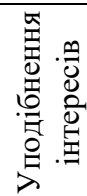 } & \multirow{2}{*}{$\begin{array}{l}\text { Уподібнення } \\
\text { інтересів }\end{array}$} & \multirow{2}{*}{$\begin{array}{c}\text { Зменшення } \\
\text { інформаційної } \\
\text { асиметрії } \\
\text { (моніторинг) }\end{array}$} & \multirow{2}{*}{$\begin{array}{l}\text { Уподібнення } \\
\text { інтересів }\end{array}$} \\
\hline & $\begin{array}{c}\text { Сигналізування/ } \\
\text { екранування }\end{array}$ & $\begin{array}{l}\text { Само- } \\
\text { відбір }\end{array}$ & & & & \\
\hline
\end{tabular}

Виходячи 3 даних таблиці 1, можна констатувати, що виникнення інформаційної асиметрії зумовлюється існуванням прихованих характеристик, прихованих дій та прихованих намірів. У результаті аналізу наведених вище видів інформаційної асиметрії можна виокремити три основні варіанти прояву опортуністичної поведінки агентів, що проявляються на передконтрактній (ex ante) та постконтрактній стадії (ex post) - несприятливий відбір, моральний ризик та утримання.

Приховані характеристики в контексті діяльності агентів - це деякі особливості такої діяльності, які невідомі до укладання контракту, однак про які усвідомлений агент, що дозволяє йому укласти такий контракт, по якому одержання винагороди буде залежати не лише від докладених ним зусиль. У результаті неврахування принципалами факту існування прихованих характеристик ними здійснюється несприятливий відбір, внаслідок якого між принципалом та агентом укладається неповний контракт на найбільш вигідних для агента умовах. Таким чином, менеджери намагаються мінімізувати власні зусилля на реалізацію контракту внаслідок відсутності у принципалів інформації про приховані характеристики об'єкта контрактних відносин. Класичним прикладом несприятливого відбору є вибір покупцями неякісних «лимонів» (уживаних автомобілів), наведений Дж.Акерлофом, стосовно яких у продавців була 
інформаційна перевага, що в цілому призвело до скорочення ринку і поступового зниження якості таких товарів. У корпоративних структурах прикладом несприятливого відбору є укладання контрактів 3 менеджерами стосовно необхідності досягнення ними завдань, які вже частково реалізовані, однак про це непоінформований принципал.

Приховані дії - це сукупність дій агента після укладання контракту, які не можуть бути перевірені принципалом внаслідок неможливості забезпечення їх постійного моніторингу, оскільки він може оцінювати ефективність діяльності агента за кінцевим результатам, а не за процедурою їх досягнення. Внаслідок можливості здійснення агентом прихованих дій виникає моральний ризик, що полягає у можливості використання альтернативних варіантів реалізації процедур в межах своєї діяльності, що вступатимуть в суперечність 3 інтересами принципала. Виникнення морального ризику характеризує ситуацію неспівпадіння інтересів принципала та агента, внаслідок чого останній веде себе інакше, ніж за обставин, коли контракт ще не було підписано. Неспівпадіння інтересів полягає в тому, що принципал хоче одержати максимальний надлишок від роботи агента, а останній не виконує свою роботу належним чином чи взагалі відмовляється від іiі виконання. Прикладом використання прихованих дій у корпоративних структурах є зловживання менеджерами обліковою політикою підприємства задля досягнення необхідних результатів діяльності за звітний період, що забезпечуватимуть одержання бажаної винагороди, а також небажання докладання всіх необхідних зусиль для забезпечення максимізації інтересів принципала. Останнє може бути пов'язано з недостатнім рівнем винагороди, яку одержує менеджер у випадку збільшення вартості корпоративної структури, оскільки він володіє значно меншою кількістю акцій порівняно з принципалами. Здійснення прихованих дій найчастіше відбувається в великих корпоративних структурах з розпорошеною власністю, де більшість акцій не контролюються корпоративними менеджерами, що є більш типовим для країн з розвиненою ринковою економікою та фондовим ринком.

Приховані наміри - це сукупність дій агента після укладання контракту, які не може спрогнозувати принципал до їх укладання та на які він не зможе більше вплинути, що відрізняє їх від прихованих дій. Зазвичай здійснення прихованих дій пов'язано зі здійсненням інвестицій принципала в специфічні активи, внаслідок чого агент може скористатися залежністю принципала від себе після укладання контракту. Утримання передбачає використання залежності принципала для забезпечення своєї власної корисності. Наприклад, укладання контрактів у корпоративній структурі з працівниками, які мають рідку та специфічну для цієї організації кваліфікацію, ставить в залежність принципала від нових вимог та прихованих побажань агента.

Можливе здійснення опортуністичної поведінки агентами внаслідок існування інформаційної асиметрії між ними та принципалами на передконтрактній та постконтрактній стадіях може призвести до краху компанії та загрожувати інтересам власників й інших заінтересованих осіб. Не дивлячись на постійне обговорення агентської проблеми в наукових колах, у сучасних компаніях продовжують виникати конфлікти між власниками капіталу та менеджерами, що призводить до появи корпоративних скандалів, які змушують шукати нові шляхи підвищення ефективності корпоративного управління, яке б задовольняло всі групи заінтересованих осіб. Наведене вище зумовлює необхідність розробки різноманітних заходів та інструментів, які дозволять зменшити або повністю ліквідувати негативні наслідки виникнення агентської проблеми в корпоративних структурах.

При цьому також слід враховувати, що вжиття окремих видів заходів, спрямованих на унеможливлення здійснення опортуністичної поведінки в умовах асиметрії інформації може призвести до придушення ініціативи та застосування творчого підходу в діяльності агентів, до зменшення інноваційності та ухилення від ризиків, що в цілому може негативно вплинути на результати діяльності корпоративної структури.

В умовах сьогодення дослідників, які займаються вивченням агентської проблеми, можна об'єднати у дві групи, виходячи 3 тих підходів, які використовуються ними для покращання процесу управління в організаціях, де існує агентська проблема. Представники першої групи - позитивісти, займаються пошуком управлінських механізмів, які обмежують можливість здійснення агентами опортуністичної поведінки, спрямованої на задоволення власних інтересів, які не збігаються з інтересами принципалів. Представники другої групи - прихильники нормативного підходу - спрямовують свою увагу на формалізацію стосунків між агентами та принципалами за рахунок удосконалення контрактних взаємодій.

Базуючись на позиціях дослідників 3 двох розглянутих груп, сучасними вченими представлено значну кількість рекомендацій, яким чином можна зменшити агентський опортунізм та як підвищити ефективність корпоративного управління, виходячи із особливостей застосовуваних моделей, особливостей національного законодавства, що регулює діяльність корпоративних структур, специфіки зовнішнього середовища тощо. Виходячи 3 того, що реалізація агентами опортуністичної поведінки відбувається по-різному залежно від наявного виду інформаційної асиметрії, тому авторами пропонуються досить різноманітні шляхи вирішення агентської проблеми (табл. 2). 
Пропозиції дослідників щุодо пом'якщення негативного впливу агентської проблеми

\begin{tabular}{|c|c|c|}
\hline $\begin{array}{l}\text { № } \\
3 / n\end{array}$ & Автор & Пропозиції щуодо вирімення агентської проблеми \\
\hline 1 & $\begin{array}{l}\text { I.С. Лозова } \\
{[3, \text { с. } 127]}\end{array}$ & $\begin{array}{l}\text { 1) перехід від короткотривалого цілепокладання і стимулювання до } \\
\text { довгострокового, співставного } 3 \text { тривалістю економічного циклу; } \\
\text { 2) розширення простору корпоративних відносин } 3 \text { врахуванням } \\
\text { інтересів всіх ключових стейкхолдерів }\end{array}$ \\
\hline 2 & $\begin{array}{l}\text { Б.Предіч, } \\
\text { М.Івановіч-Дукіч } \\
\text { [15, с. } 1-12]\end{array}$ & $\begin{array}{l}\text { 1) створення наглядового органу для контролю за роботою менеджерів; } \\
\text { 2) співвідношення премій для менеджерів } 3 \text { прибутком акціонерів; } \\
\text { 3) концентрація власності; 4) публікація інформації та фінансова } \\
\text { прозорість; 5) інші заходи, які можуть стимулювати менеджерів } \\
\text { працювати в інтересах акціонерів }\end{array}$ \\
\hline 3 & $\begin{array}{l}\text { М.Бошкоска } \\
{[8, \text { с. } 205-206]}\end{array}$ & $\begin{array}{l}\text { 1) внутрішні заходи (внутрішній аудит, зміна зарплат та виплат } \\
\text { керівників, концентрація права власності, гарне корпоративне } \\
\text { регулювання / управління); 2) зовнішні заходи (зовнішній аудит, ринок } \\
\text { капіталу, закон / законодавча база) }\end{array}$ \\
\hline 4 & $\begin{array}{l}\text { А.В. Лібман } \\
{[2, \text { с. } 35-52]}\end{array}$ & $\begin{array}{l}\text { 1) внутрішні механізми (структура управління корпорації, участь ради } \\
\text { директорів, усунення інформаційної асиметрії); 2) захист прав } \\
\text { інвесторів (удосконалення законодавчих норм, посилення прав } \\
\text { акціонерів, посилення прав кредиторів) }\end{array}$ \\
\hline 5 & $\begin{array}{l}\text { М.Андріяшевич, } \\
\text { В.Пашич [6] }\end{array}$ & $\begin{array}{l}\text { 1) удосконалення структури власності; 2) посилення контролю } \\
\text { інвесторів; 3) використанні ринкових індикаторів; 4) посилення вимог } \\
\text { щодо управління капіталом менеджерами }\end{array}$ \\
\hline 6 & $\begin{array}{l}\text { В.І. Павлов, } \\
\text { О.А. Мишко } \\
{[4, \text { с. } 47]} \\
\end{array}$ & $\begin{array}{l}\text { 1) удосконалення законодавства; 2) запровадження добровільних } \\
\text { заходів (стандарти, прийняті учасниками корпоративних відносин) }\end{array}$ \\
\hline 7 & $\begin{array}{l}\text { Ю.Чен } \\
{[9, \text { c. } 38-58]}\end{array}$ & $\begin{array}{l}\text { 1) структура власності; 2) рада директорів; 3) дивідендна політика; } \\
\text { 4) зовнішній аудит. }\end{array}$ \\
\hline 8 & $\begin{array}{c}\text { Г.Демсец, К.Лен } \\
{[10, \text { с. } 1175-1176]}\end{array}$ & $\begin{array}{l}\text { Удосконалення структури власності, зокрема, збільшення кількості } \\
\text { великих зовнішніх акціонерів }\end{array}$ \\
\hline 9 & $\begin{array}{l}\text { С.Фама, } \\
\text { М.Дженсен } \\
{[11, \text { с. } 311]}\end{array}$ & посилення моніторингу ради директорів за менеджментом організацій \\
\hline 10 & $\begin{array}{l}\text { А.Пікот, } \\
\text { Р. Рейхвальд, } \\
\text { Р.Т. Віганд } \\
{[14, \text { с. } 50]}\end{array}$ & $\begin{array}{l}\text { 1) сигналізування/екранування; 2) самовідбір; 3) уподібнення інтересів; } \\
\text { 4) моніторинг }\end{array}$ \\
\hline
\end{tabular}

Наведені в таблиці 2 пропозиції дослідників щодо пом'якшення негативного впливу агентської проблеми, виходячи 3 шляхів одержання наукових результатів можна об'єднати в дві наступні групи: 1) Синтетичний підхід; 2) Аналітичний підхід. Представники синтетичного підходу намагаються виявити та проаналізувати всі можливі варіанти мінімізації агентської проблеми, а представники аналітичного підходу - один або декілька таких варіантів, намагаючись довести ефективність їх використання для конкретних груп або видів підприємств, які відносяться до окремої галузі або функціонують в рамках законодавства окремої країни чи певного територіального утворення. Всі зазначені пропозиції дослідників потрапляють до внутрішнього або зовнішнього механізму корпоративного управління, тобто стосуються інструментів управління всередині корпоративної структури, або пов'язані зі змінами в ії зовнішньому середовищі.

Окрім цього, існуючі пропозиції вчених також можна класифікувати в контексті нормативнопозитивної дихотомії дослідників агентської проблеми. Так одна частина пропозицій дослідників спрямована на ліквідацію негативного впливу агентської проблеми за рахунок постійного та всебічного моніторингу принципалами діяльності агентів, яким передаються повноваження на управління організацією, здійснення додаткового стимулювання їх діяльності тощо. Інша частина пропозицій стосується розвитку процедурних та змістовних аспектів укладання контракту між агентами та принципалами, які б дозволили на даній фазі створити більш сприятливі умови для виконання агентами своїх обов'язків таким чином, щоб вони не суперечили інтересам принципалів. При цьому, як показує аналіз праць дослідників, наведених в таблиці 2, жодна 3 пропозицій не дозволяє повною мірою вирішити агентську проблему в корпоративних структурах. Це пов'язано як з тим, що принципали не 
можуть повноцінно і адекватно здійснювати моніторинг діяльності агентів через наявність інформаційної асиметрії (здійснення прихованих дій та наявності прихованих намірів), так і 3 неможливістю сформулювати всебічно визначений контракт через неможливість перебачити всі можливі ситуації, в яких агент може опинитися в момент виконання делегованих на нього повноважень, та через неможливість виявити всі приховані характеристики, пов'язані з діяльністю агентів. Хоча деякі дослідники замість двох вказаних вище груп пропозицій пропонують використовувати компромісний варіант, який передбачає одночасне застосування стимулюючих заходів щодо діяльності агентів та проведення певного моніторингу, вони також не дозволяють вирішити агентську проблему повною мірою.

Таким чином, в сукупності внутрішні та зовнішні механізми корпоративного управління дозволяють лише пом'якшити наслідки агентської проблеми, а не забезпечити ії повноцінне вирішення. Основною причиною цього $\epsilon$ те, що ті інструменти і заходи, які є оптимальними для однієї корпоративної структури в певний момент часу, не будуть такими ж оптимальними для інших корпоративних структур. Подібної позиції дотримується П.МакКолган, зауважуючи, що обсяг кожного типу агентських конфліктів буде відрізнятися від однієї фірми до іншої, як і ефективність механізмів управління в їх зменшення. Кожен тип механізму управління може мати важливе значення у зменшенні агентських витрат на поділ власності та контролю. Потрібне більш детальне розуміння того, що робить ці механізми важливими для одних фірм та неефективними для інших [13, с. 58]. Відповідно, агентська проблема може бути зменшена шляхом використання ефективних механізмів корпоративного управління, які можуть мати важливе значення у зменшенні агентських витрат на розподіл власності та контролю у одних корпоративних структурах, однак не матимуть подібного ефекту в інших.

Таку думку також підтверджує проведене І.В. Шевченко та М.В. Курузовим дослідження агентських конфліктів, під якими в корпоративних структурах слід розуміти зіткнення протилежних інтересів між учасниками агентських відносин в них, що спочатку призводить до робочих ускладнень, а в кінцевому випадку може мати значні фінансові наслідки, що характеризуватимуться зростанням агентських витрат. Виходячи з виокремленої авторами класифікації агентських конфліктів у корпоративних структурах за п'ятьма ознаками (залежно від суб'єктів-учасників; залежно від місця виникнення конфлікту; залежно від напрямів проблематики; в залежності від способу виникнення конфлікту; залежно від наявності агентських витрат) [5, с. 27] можна констатувати, що існують різноманітні види агентських конфліктів, які мають відмінну природу їх появи, що зумовлює необхідність використання різноманітних підходів та інструментів для їх вирішення. Відповідно, розвиток внутрішнього та зовнішнього середовища корпоративної структури впливають на особливості виникнення в ній агентських конфліктів, тим самим зумовлюючи необхідність застосування для їх подолання таких заходів, які б враховували такі особливості і дозволяли досягти максимального ефекту від їх використання.

В усуненні агентської проблеми в корпоративних структурах важливу роль також відіграє система бухгалтерського обліку, яка 3 одного боку, $є$ основним інформаційним джерелом, яке дозволяє принципалам слідкувати за ефективністю функціонування агентів в межах делегованих ним повноважень, а 3 другого - $є$ однією з причин виникнення інформаційної асиметрії, існування якої $\epsilon$ передумовою для здійснення агентами опортуністичної поведінки.

Однак надання звітної фінансової інформації членам ради директорів та акціонерам $\epsilon$ лише загальною і найбільш поширеною практикою, яка свідчить про роль бухгалтерського обліку в системі корпоративного управління. Насправді вона є значно більшою, про що зауважують К.Робертс, П.Уітман та П.Гордон, зазначаючи, що бухгалтерська інформація використовується для контролю поведінки менеджерів у випадках, які можна проілюструвати за допомогою таких питань:

1. Як часто бухгалтерська інформація використовується для визначення розміру компенсації менеджерів у схемах винагород?

2. Як використовується бухгалтерська інформація при прийнятті рішення про зміну головного виконавчого директора?

3. Як застосовується бухгалтерська інформація при укладанні договорів про одержання позик? Як бухгалтерська інформація використовується в інших формах фінансових контрактів, таких як використання бухгалтерської інформації для обмеження можливості компанії виплачувати дивіденди?

4. Як бухгалтерська інформація використовується керівництвом для зменшення ризиків судових процесів 3 акціонерами, спричинених упущеннями або викривленнями при розкритті звітності? [16, с. 125].

Таким чином, з позиції розвитку механізмів підвищення ефективності корпоративного управління, спрямованих на мінімізацію наслідків агентської проблеми, важливого значення набуває не лише удосконалення порядку представлення інформації в фінансовій звітності (порядку іï формування на основі використання інструментів облікової політики, креативного обліку, порядку їі представлення та візуалізації в бухгалтерській звітності), а також і удосконалення механізмів додаткового розкриття облікової інформації, необхідної для прийняття специфічних корпоративних рішень (в примітках до 
фінансової звітності, в звітах, що одночасно включають фінансову та нефінансову інформацію (звіт про управління, інтегрована звітність) тощо).

Висновки та перспективи подальших досліджень. Одним 3 факторів, що впливає на ефективність функціонування корпоративних структур, є здатність їх керівництва створити передумови для мінімізації агентської проблеми. Дане питання на сьогодні $є$ однією з актуальних тем для досліджень і вимагає приділення особливої уваги на сучасному етапі становлення корпоративного сектору в Україні.

Проведений аналіз дозволив встановити, що однією з основних причин виникнення агентської проблеми є існування інформаційної асиметрії між принципалами та агентами, що дозволяє здійснювати останнім опортуністичну поведінку, спрямовану на задоволення власних інтересів. Для уникнення такої поведінки власники корпоративної структури змушені нести агентські витрати, які слід розглядати як засоби усунення причин і наслідків виникнення інформаційної асиметрії. На основі аналізу наслідків виникнення інформаційної асиметрії (несприятливий відбір, моральний ризик, утримання) на передконтрактній та постконтрактній стадіях обгрунтовано їх роль у виникненні корпоративних конфліктів, що породжується неспівпадінням інтересів принципалів та агентів.

У результаті вивчення пропозицій дослідників щодо пом'якшення негативного впливу агентської проблеми встановлено, що вони передбачають здійснення двох варіантів дій: 1) ліквідація негативного впливу агентської проблеми за рахунок постійного та всебічного моніторингу принципалами діяльності агентів; 2) розвиток процедурних та змістовних аспектів укладання контракту між агентами та принципалами. Для забезпечення ефективної реалізації кожного з варіантів необхідним є використання облікової інформації. Так для першого варіанта необхідним є надання інформації щодо ефективності функціонування агентів та об’єктивної оцінки результатів їх діяльності. За другим варіантом облікова система має забезпечити надання інформації, яка б дозволила укладання оптимальних контрактів між принципалами та агентами, які б не дозволяли в майбутньому здійснювати останнім опортуністичну поведінку. Відповідно, виокремлені завдання щодо необхідності формування облікової інформації для двох варіантів дій щодо мінімізації наслідків виникнення агентської проблеми повинні розглядатись як напрями подальшого удосконалення облікової системи в цілому, в основі яких має бути покладена неоінституційна теорія бухгалтерського обліку.

Список використаної літератури:

1. Акерлоф Дж. Рынок «лимонов»: неопределенность качества и рыночный механизм / Дж.Акерлоф // THESIS. - 1994. - Вып. 5. - С. 91-104.

2. Либман B.A. Меры по регламентации корпоративного управления как способ решения агентской проблемы / В.А. Либман // Вестник СПБГУ. - 2003. - Сер. 8, Вып. 1 (8). - С. 34-54.

3. Лозовая И.С. Агентская проблема в управлении корпорацией: истоки, современное состояние, возможные пути решения / И.С. Лозовая // Каспийский регион: политика, экономика, культура. - 2011. - № 1 (26). C. $124-129$.

4. Павлов B.I. Корпоративне управління в акціонерних товариствах : монографія / В.І. Павлов, О.А. Мишко.Луцьк : Надстир'я ; Рівне : НУВГП, 2006. - 180 с.

5. Шевченко И.В. Внутрикорпоративные агентские конфликты и их классификация / И.В. Шевченко, М.В. Курузов // Финансы и кредит. - 2014. - № 10 (586). - С. 25-30.

6. Andrijašević M. Theoretical assumptions of agency problem / M.Andrijašević, V.Pašić // Second international symposium on natural resources management, Faculty of management [Electronic recourse]. - Access mode : https://www.researchgate.net/publication/322701162_theoretical_assumptions_of_agency_problem.

7. Arrow K.J. Information Structure of the Firm / K.J. Arrow // American Economic Review. - 1985. - Vol. 75, No. 2. - P. 303-307.

8. Boshkoska M. The agency problem: measures for its overcoming / M.Boshkoska // International Journal of Business and Management. - 2015. - Vol. 10, No. 1. - P. 204-209.

9. Chen $Y u$. Agency issues and the effects of corporate governance mechanisms on agency costs in chinese listed companies / Yu.Chen // A Thesis Submitted in Fulfilment of the Requirements for the Degree of Doctor of Philosophy of Cardiff University. - 2010. - 247 p.

10. Demsetz H. The Structure of Corporate Ownership: Causes and Consequences / H.Demsetz, K.Lehn // Journal of Political Economy. - 1985. - Vol. 93, No. 6 (Dec.). - P. 1155-1177.

11. Fama E.F. Separation of Ownership and Control / E.F. Fama, M.C. Jensen // Journal of Law and Economics. 1983. - Vol. 26, No. 2 (Jun.). - P. 301-325.

12. Jensen M.C. Theory of the firm: managerial behavior, agency costs and ownership structure / M.C. Jensen, W.H. Meckling // Journal of Financial Economics. - 1976. - Vol. 3, № 4. - P. 305-360.

13. McColgan P. Agency theory and corporate governance: a review of the literature from a UK perspective / P.McColgan // Department of Accounting \& Finance / University of Strathclyde. - Glasgow, 2001. - 77 p. [Electronic resource]. Access mode $:$ http://citeseerx.ist.psu.edu/viewdoc/download?doi=10.1.1.202.286\&rep=rep1\&type=pdf.

14. Picot A. Information, Organization and Management / A.Picot, R.Reichwald, R.T. Wigand. - Springer Science \& Business Media, 2008. - $536 \mathrm{p}$.

15. Predić B. Methods to solve agency problems / B.Predić, M.Ivanović-Đukić // Economic Themes Magazine. 2010. - № 1. - P. 1-12. 
16. Roberts C. International Financial Reporting. A Comparative Approach / C.Roberts, P.Weetman, P.Gordon.-3 ed. - Pearson Education Limited, 2005. -708 p.

\section{References:}

1. Akerlof, Dzh. (1994), «Rynok «limonov»: neopredelennost' kachestva i rynochnyj mehanizm», THESIS, Vol. 5, pp. 91-104.

2. Libman, V.A. (2003), «Mery po reglamentacii korporativnogo upravlenija kak sposob reshenija agentskoj problemy», Vestnik SPBGU, Series 8, Vol. 1 (8), pp. 34-54.

3. Lozovaja, I.S. (2011), «Agentskaja problema v upravlenii korporaciej: istoki, sovremennoe sostojanie, vozmozhnye puti reshenija», Kaspijskij region: politika, jekonomika, kul'tura, No. 1 (26), pp. 124-129.

4. Pavlov, V.I. and Myshko, O.A. (2006), Korporatyvne upravlinnja v akcionernyh tovarystvah, monografija, Nadstyr'ja, NUVGP, Luc'k, Rivne, 180 p.

5. Shevchenko, I.V. and Kuruzov, M.V. (2014), «Vnutrikorporativnye agentskie konflikty i ih klassifikacija», Finansy i kredit, No. 10 (586), pp. 25-30.

6. Andrijašević, M. and Pašić, V., «Theoretical assumptions of agency problem Second international symposium on natural resources management», Faculty of management, [Online], available at: https://www.researchgate.net/publication/322701162_theoretical_assumptions_of_agency_problem

7. Arrow, K.J. (1985), «Information Structure of the Firm», American Economic Review, Vol. 75, No. 2, pp. $303-307$.

8. Boshkoska, M. (2015), «The agency problem: measures for its overcoming», International Journal of Business and Management, Vol. 10, No. 1, pp. 204-209.

9. Chen, Yu. (2010), «Agency issues and the effects of corporate governance mechanisms on agency costs in chinese listed companies», A Thesis Submitted in Fulfilment of the Requirements for the Degree of Doctor of Philosophy of Cardiff University, $247 \mathrm{p}$.

10. Demsetz, H. and Lehn, K. (1985), «The Structure of Corporate Ownership: Causes and Consequences», Journal of Political Economy, Vol. 93, No. 6 (Dec.), pp. 1155-1177.

11. Fama, E.F. and Jensen, M.C. (1983), «Separation of Ownership and Control», Journal of Law and Economics, Vol. 26, No. 2 (Jun.), pp. 301-325.

12. Jensen, M.C. and Meckling, W.H. (1976), «Theory of the firm: managerial behavior, agency costs and ownership structure», Journal of Financial Economics, Vol. 3, No. 4, pp. 305-360.

13. McColgan, P. (2001), "Agency theory and corporate governance: a review of the literature from a UK perspective», Department of Accounting \& Finance, University of Strathclyde, Glasgow, 77 p., [Online], available at: http://citeseerx.ist.psu.edu/viewdoc/download?doi=10.1.1.202.286\&rep=rep1\&type=pdf

14. Picot, A., Reichwald, R. and Wigand, R.T. (2008), Information, Organization and Management, Springer Science \& Business Media, $536 \mathrm{p}$.

15. Predić, B. and Ivanović-Đukić, M. (2010), «Methods to solve agency problems», Economic Themes Magazine, No. 1, pp. 1-12.

16. Roberts, C., Weetman, P. and Gordon, P. (2005), International Financial Reporting. A Comparative Approach, in $3^{\text {rd }}$ ed., Pearson Education Limited, 708 p.

Царук Василь Юрійович - кандидат економічних наук, доцент кафедри обліку та економікоправового забезпечення агропромислового бізнесу Тернопільського національного економічного університету.

Наукові інтереси:

- теорія корпоративного управління;

- розвиток обліково-аналітичного забезпечення корпоративного управління;

- інституційна теорія обліку. 